\title{
Explaining Innovation. An Empirical Analysis of Industry Data from Norway
}

\section{Torbjørn Lorentzen ${ }^{1}$ and Stig-Erik Jakobsen²}

\begin{abstract}
The objective of the paper is to analyse why some firms innovate while others do not. The paper combines different theories of innovation by relating innovation to internal, firm specific assets and external, regional factors. Hypotheses are derived from theories and tested empirically by using logistic regression. The empirical analysis indicates that internal funding of $R \& D$ and size of the firm are the most important firm specific attributes for successful innovation. External, regional factors are also important. The analysis shows that firms located in large urban regions have significantly higher innovation rates than firms located in the periphery, and firms involved in regional networking are more likely to innovate compared to firms not involved in networking. The analysis contributes to a theoretical and empirical understanding of factors that influence on innovation and the role innovation plays in the market economy. Innovation policy should be targeted at developing a tax system and building infrastructure which give firms incentives to invest and allocate internal resources to $R \& D$-activities and collaborate with others in innovation. From an economic policy perspective, consideration should be given to allocating more public resources to rural areas in order to compensate for the asymmetric distribution of resources between the centre and periphery. The paper contributes to the scientific literature of innovation by combining the firm oriented perspective with weight on firm specific, internal resources and a system perspective which focuses on external resources and networking as the most important determinants of innovation in firms. Keywords: innovation, region, location, centre and periphery, firm specific and external resources, networking, Norwegian industry, logistic regression.
\end{abstract}

\section{INTRODUCTION}

Theoretical and applied research in the field of innovation emphasizes different factors in the explanation and the role innovation plays in the economy; Fagerberg (2005) shows how innovation enhances competitiveness

1 Torbjørn Lorentzen, M.A., Uni Research, University of Bergen, Allegaten 70, N-5007 Bergen, e-mail: torbjorn.lorentzen@ uni.no.

2 Stig-Erik Jakobsen, Professor, Bergen University College, P.O.Box 7030, N-5020 Bergen, Norway, e-mail: Stig-Erik. Jakobsen@hib.no. 
and productivity in firms. Christensen and Raynor (2003) argue that firms have to innovate in order to adapt and survive in a market economy. Analyses by Audretsh and Feldman (1996, 2003), Porter (2000), Fabrizio and Thomas (2011), Isaksen and Onsager (2010), Laursen, Masciarelli and Prenicpe (2012) and Lorentzen and Jakobsen (2015) show how sectorial and spatial differences are an influence on the rate of innovation collaboration. Studies indicate that R\&D-activities and major product innovation seem to be concentrated to metropolitan regions (Fritsch, 2003; Simmie, 2003), and that firms in rural areas are often less innovative than firms in other areas (Tödtling \& Trippl, 2005). It is also argued that firms in high-tech industries are more innovative than firms in low-tech industries (Tödtling \& Trippl, 2007; Trott, 2012).

The referred literature has not explicitly focused on the question why some firms innovate and others do not. In this paper we want to answer the question by combining firm- and system oriented approaches in the explanation of innovation, and by using observational innovation-data at firm level in a statistical analysis. The paper contributes to the literature in two ways. Firstly, by combining the theories we follow a holistic approach which is more complete and comprehensive compared to explaining innovation by using a single theory or using the theories side-by-side. By combining theories we try to eliminate the problem with reductionism. An argument for combining theories in a holistic way is that it provides us with a better and more complete understanding of the mechanisms involved in the explanation of innovation compared to reducing it to a single factor. Secondly, the paper contributes to the literature by estimating a statistical model which includes explanatory variables which are derived from both main theoretical perspectives. By including explanatory variables from both theories in the model we can estimate the effect each variable has on the dependent variable controlled for the potential influence the other variables have on the dependent variable. Therefore the scientific approach makes it possible to test both theories simultaneously. The empirical part of the paper operationalizes concepts derived from both theories, and the logistic regression methodology is applied in analysing how firm-specific factors and regional characteristics in combination have an influence on the innovation rate among firms in the Norwegian economy.

The rest of the paper is organized as follows. The next section presents the theoretical framework applied in the analysis. We identify four attributes related to internal, firm-specific characteristics (size of the firm, sector, R\&D personnel and own-financed R\&D activity) and two are related to external, regional characteristics (the size and the quality of the region). We estimate a single model and test statistically how these various firm and regional characteristics together are an influence on the firms' propensity to innovate. 
The empirical methodology and estimation results are presented in the subsequent sections. The concluding section summarizes the findings and presents policy implications. The empirical analysis is based on the Norwegian Community Innovation Survey (CIS 2008) and cover the 2006-2008 period. The statistical analysis includes 8524 firms. This survey was conducted by Statistics Norway as part of the pan-European CIS, and coordinated by Eurostat, the EU statistics agency. The questionnaire is based on definitions of innovation input and output as presented in the OECDs Oslo Manual.

\section{THEORETICAL FRAMEWORK}

Schumpeter $(1934,1943)$ argued that innovations are the fundamental impulses that set and keep the capitalist engine in motion. He defined innovations as new combinations of existing resources, such as new products, methods of production, sources of supply and ways of organizing business, as well as the exploitation of new markets. Firms need knowledge, skills and entrepreneurial abilities to innovate, and according to Schumpeter, not all firms possess these resources (Schumpeter, 1934). He argued that innovations are not "evenly distributed through time" but "appear, if at all, discontinuously in groups or swarms" (Schumpeter, 1934, p. 223). We can derive two important assumptions from these observations. First, disproportionate patterns of innovation can be linked to the fact that firms have different resources and different abilities to innovate; and second, some firms may have more favourable or productive environments for innovation than other firms. The first type of observation reflects the firm-oriented and management-inspired perspective in the innovation literature, while the second type of observation reflects the system-oriented perspective on innovation. The following section presents the firm- and system-perspective on innovation.

\section{A firm perspective on innovation}

In some neoclassical-inspired writings, firms are "black boxes" that only respond to changing market conditions. Firms seek optimal solutions, and their strategies and innovation practices are determined by the market size and conditions they face (Newell, Jaffe \& Stavins, 1999). Because of the importance of innovation for economic growth, it is essential to clarify how firms differ and to specify which characteristics make firms innovative. We need to know why some firms have a good record of transforming resources into new goods and services or other innovations that customers are willing to pay for, whereas others seem less able to do this (Lazonick, 2005). Consequently, we have to elaborate on the sources of such inter-firm differences. 
A fruitful approach for understanding such firm heterogeneity is the resource-based view of the firm. This assumes that firms are diverse, and treats firms as historical entities with unique characteristics (Foss, Knudsen \& Montgomery, 1995). The resource-based view has its roots in the work of Penrose (1959) and early strategy theory (e.g., Chandler, 1962). This perspective states that the competitiveness and performance of a company depend on the extent its endowment of resources differentiates it from its competitors (Rangone, 1999). Organizations vary in their resources, and in the capabilities that those resources afford them. Resources become capabilities when they contribute to sustainable competitive advantages, which occur when resources generate differences in efficiency, are difficult to imitate, or are unique (Wernfeldt, 1984). This perspective is focusing on how firms make the most of available resources to be competitive and innovative. In their dynamic resource based perspective, Teece and Pisano (1994) argue that the most important competitive advantage of firms is their ability to reconfigure internal and external competences (see also Teece, Pisano \& Schuen, 1997). Lawson and Samson (2001) propose the concept of innovation capability, defined as a firm's ability to continuously transform knowledge and ideas into new products and processes. The theory also assumes that large firms have more resources and more capabilities than small firms, and that those firms in capital- and knowledge-intensive industries have more technological resources and know-how than firms in more traditional sectors of the industry. Consequently, larger firms and high-tech firms are more likely to innovate (Fagerberg, 2009). However, larger firms also face the particular challenge of simultaneously managing existing products and developing new and innovative products (Tushman \& O'Reilly, 2002).

Within the resource based view there are also contributions inspired by evolutionary thinking focusing on how firms' capabilities evolve over time. According to Nelson and Winter (1982), three features of firms are essential to innovation. The first essential feature concerns the structural characteristics of firms, which are associated with the business sector in which the firm does business (type of firm), the size of the firm and its organizational character. Among other things, the latter characteristic concerns whether firms have their own R\&D organization and, if so, the higher the number of highly competent R\&D personnel they have, the higher is the likelihood of innovation. Highly competent human capital is an important asset for innovation practice. A second feature that is essential to innovation is the core capabilities the firm has developed through time. As pointed out above, such capabilities are essential for differentiating the firm from its competitors. The third essential feature is a firm's strategy, or the broad set of commitments that define its objectives and how it intends to pursue them (Nelson, 1991). These abilities 
or features do vary between firms, and they can also vary through time within a single firm. A firm can change from being an innovation leader to an innovation laggard when choices in the past result in technological and organizational rigidity (Njøs, Jakobsen, Fosse \& Engelsen, 2016).

\section{A systems perspective on innovation}

Whereas the firm-oriented perspective emphasizes a firm's internal resources, the system-oriented perspective focuses on the environment or the socio-economic context in which the firm does business. It can be argued that a firm's propensity to innovate reflects characteristics of the firm's environment, i.e., possibilities for networking, infrastructure, regional resources etc. (Cooke, 1992, 2001; Fagerberg, 2005; Fløysand \& Jakobsen, 2011; Fløysand, 2012; Lundvall, 1992). Thus, the competiveness of firms is directly linked to their location. The concept of externalities is important in this line of thought. The co-location of firms generates economic advantages or positive external effects (Audretsch \& Feldman 1996; 2004). Such effects are collectively produced and spill over to spatially proximate firms as "free" goods (Vatne, 2011). There are different types of externalities, and Hoover (1954) distinguishes between "location economies" and "urbanization economies". "Location economies" refers to the co-location of firms that are in the same or related industries. Such specialized industrial milieus are expected to generate technological spill overs between firms and specialized labour markets (Marshall, 1920). "Urbanization economies", or Jacob's externalities, refer to the advantages of being located in larger diversified regions, such as a region with an advanced physical infrastructure and transportation system that affords access to well-developed and comprehensive private and public services. The larger the region, the greater the opportunity for both location and urbanization economies, and the greater are the potential for positive effects on a firm's ability to innovate.

Freeman (1987) and Lundvall (1992) argue that innovation must be understood as an open, dynamic process, involving networking, learning and feedback loops among various types of actors such as R\&D institutions and political authorities. Other studies have emphasized the importance of external knowledge sourcing for innovation (Enkel, Gassmann \& Chesbrough, 2009; Clausen, 2013). Although Lundvall (1992) focused on national systems of innovation, Cooke $(1992,2001)$ developed his ideas around the concept of regional innovation systems. The emphasis on the regional level is partly based on the observation that externalities, which are essential in processes of interactive innovation, tend to be spatially bounded and decrease with distance. According to Autio (1998) and Tödtling and 
Trippl (2005), a regional innovation system consists of two subsystems. The first subsystem concerns the exploitation and application of knowledge, and comprises firms and their clients, suppliers, competitors and co-operating partners. The second subsystem concerns the generation and diffusion of knowledge, which involves various institutions engaged in the production and diffusion of knowledge, such as universities, university colleges, research institutions and mediating organizations. In addition, there is a political sphere, which refers to those institutions that formulate, implement and maintain policy instruments. The essence of these lines of thoughts is that regional systems differ in size and structure, and those differences influence a firm's propensity to innovate (Cooke, 2012; Laursen et al., 2012; Malecki, 2012). For instance, some regional innovation systems are characterized by weak institutional structures, and few networks between firms and reactive policies. Thus, the prerequisites for such a regional innovation system are weakly developed. Other regions are characterized by knowledge-intensive industries, intense networking, several R\&D institutions and proactive policies (Fløysand, Jakobsen \& Sánchez-Hernández, 2014; Isaksen \& Trippl, 2014; Jakobsen, et al., 2012; Njøs, et al., 2013; Tödtling \& Trippl, 2005). Given a system perspective, it is expected that the latter, regional environment has a greater positive influence on the innovation rate than the former (Fløysand \& Jakobsen 2016).

\section{TOWARD AN ANALYTICAL MODEL}

We start this section by describing the variables included in the statistical model. Thereafter we present and estimate the model, and finally test and interpret results of the theory-based hypotheses.

We are interested in factors that determine: why some firms innovate while others do not. According to the objective of the paper we will integrate the firm- and the system-oriented approaches in the empirical analysis. Innovation is the dependent variable in the model and it includes product innovation, process innovation, market innovation, and organization innovation. The application of the term "innovation" is consistent with Schumpeter's definition. Based on the principles of the CIS survey, we categorize firms as innovative if they reported one or more innovations during $2006-2008$. About $48 \%$ of the firms included in the sample have reported one or more innovations. The construction of the analytical model (see Figure 1) depends upon the variables, definitions and categories in the CIS-survey. Our sample consists of 8524 firms.

The independent variables are attributes or characteristics that, according to the presented theories, influence a firm's propensity to innovate. The 
objective is to analyse whether there is a systematic relationship between innovation and one or more of these attributes. Informed by our theoretical discussion, we differentiate between firm characteristics and regional characteristics. We identify four attributes related to firms (firm size, sector, R\&D personnel and own-financed R\&D) and two regional attributes (size of the region and the quality of the region).

(i) Firm size: The firms are grouped into the following five size categories: 5-9 employees, 10-19 employees, 20-49 employees, 50-99 employees, and 100 or more employees. Size of the firm is a proxy variable for different firmspecific factors which influence the propensity to innovate.

(ii) Sector: The second firm-specific attribute is the industrial sector the firm is part of. We classified firms into five sub-sectors: primary industry, "lowtech" manufacturing industry, "high-tech" manufacturing industry, trade and transport industry, and knowledge intensive services.

(iii) R\&D personnel: Firms reported whether they employ R\&D personnel, i.e. personnel that are dedicated to do research as an integrated part of the firm's activity. In line with the definition used by Statistics Norway in the CIS survey, we have restricted the category to personnel with higher education (at least master's degree or similar).

(iv) Own-financed R\&D: The variable is a firm-specific characteristic and measures whether the R\&D activity in the firm is own-financed or ownfunded. The variable is a binary variable where 1 indicates that the firm has funded their R\&D by using its financial resources (equity) and 0 if they use external financial resources. In many cases firms combine own-financing with external funding. Firms without own-financing (the value 0 ) are funding their R\&D activity solely through external investors or by using economic instruments (public loans or public grants).

(v) Size of the region: Firms' locations were mapped in the survey and represent one of the proxy variables which operationalize external attributes in the explanation of variation in innovation. Jukvam (2002) has used numbers of inhabitants and centrality and divided Norway into the following five different types of regions: the capital region of Oslo (1 million or more inhabitants), metropolitan regions (between 200,000 and 999,999 inhabitants); medium-city regions (between 50,000 and 199,999 inhabitants), small-city regions (between 10,000 and 49,999 inhabitants), and rural regions (fewer than 10,000 inhabitants).

(vi) The quality of the region: The variable is the second proxy for what we define as "external attributes" or regional characteristics and it measures the quality of the region where the firms are located. There are distinct territorial variations, and although some firms are located in regions with a high degree of collaboration and networking (i.e. high quality regions), other 
firms are located in regions characterized by a lack of co-operating partners and actual network arrangements (i.e. low quality regions).

Figure 1 summarizes the various indicators which we expect have an influence on the innovation process. The arrow indicates the direction of cause and effect. The statistical model which we estimate in the next section is based on Figure 1.

Firm characteristics:

(i) Firm size

(ii) Sector

(iii) $\mathrm{R} \& \mathrm{D}$ personnel

(iv) Capital

Regional characteristics:

(v) Size of the region

(vi) Quality of the region

Figure 1. Analytical model

\section{METHODOLOGY AND STATISTICAL ANALYSIS}

The following section presents the statistical model applied in the estimation of the relationship between the likelihood of innovation and the set of explanatory variables derived from the theories (see Figure 1). The dependent variable measures whether a firm innovates or not. The independent or explanatory variables are the attributes, i.e. four firm-related attributes (size, industry sector, R\&D personnel and own financed R\&D) and two regional attributes (size and quality of the region) that we believe, in accordance with the presented theories, influence a firm's propensity to innovate.

We use $y_{i}$ to denote the dependent variable for firm " $i$ " and assign a value 1 if the firm has registered an innovation and 0 otherwise. The explanatory variables $x_{j}$, i.e. the six attributes $j=1,2, \ldots ., 6$ applied in the model are all dichotomous variables. "Innovation" is a general term and it includes product innovation (26\%), process innovation (22\%), market innovation $(26 \%)$ and organizational innovation (26\%). The number in parenthesis is the percentage 
of the total number of registered innovations in the sample. In total, about $48 \%$ of the firms in our survey reported one or more of these innovations. The dependent variable $y$ is defined as:

$$
y=\left\{\begin{array}{l}
1 \text { if the firm has registered an innovation } \\
0 \text { otherwise. }
\end{array}\right.
$$

Because the dependent variable is dichotomous, we used a binarychoice modelling approach, which is also referred to as a qualitative response regression model. The qualitative response model assumes that a firm either innovates or not innovates and that the state depends upon the attributes of the firms and the characteristics of the environment they operate in.

If we have information about the attributes of each firm and whether they have registered an innovation or not in the examination period, we can predict the likelihood of innovation. The primary objective is to determine the probability that a firm or company with a given set of attributes produces a successful innovation. In the section that follows, we estimate a logit model that quantifies the relationship between a set of firm attributes and that the firm successfully innovates.

By estimating the logit coefficients in the model, we are able to evaluate the probability of innovation based on different categories or attributes. The model makes it possible to compare estimated probabilities between categories (both firms and regional characteristics), and we can evaluate, for example, the potential effect private funding has on the likelihood of innovation or the importance of location in a metropolitan area. We can impose restrictions on the coefficients and test similarities between categories. The strength of the attribute effects is important in identifying the most likely combination of categories that contributes to innovation. Table 1 gives an overview of and defines the variables used in the model. The far right column shows the number of observations by category.

The theoretical logit model can be expressed in the following way (Formula 1):

$$
z=\log \left[\frac{\operatorname{Pr}(\text { innovation })}{1-\operatorname{Pr}(\text { innovation })}\right]=\alpha+\sum_{j=1}^{k} \beta_{j} x_{j}+\varepsilon
$$

where $z$ measures the logit or log odds ratio of innovation, i.e. the natural logarithm of the ratio between the likelihood of innovation and the likelihood 
of non- innovation, $\operatorname{Pr}(\cdot)$ is an abbreviation for the probability or likelihood of innovation, $x_{j}$ is the innovation attributes $j=1, \ldots, k$ described above (see also Table 1 ), $\mathcal{E}$ represents the error term and $k$ is the number of explanatory variables in the model.

Table 1. Description of the dependent and independent variables in the model

\begin{tabular}{|c|c|c|}
\hline Type of variable & Dummy = 1 & $\begin{array}{l}\text { Number of } \\
\text { observations by } \\
\text { category }\end{array}$ \\
\hline$y$ & $\begin{array}{l}\text { Firm " } i \text { " has registered an innovation } \\
\text { during the examination period. }\end{array}$ & 4061 \\
\hline \multicolumn{3}{|c|}{ Location of the firm } \\
\hline$x_{1}$ & Capital region & 1982 \\
\hline$x_{2}$ & Metropolitan region & 1831 \\
\hline$x_{3}$ & Medium-city region & 2577 \\
\hline$x_{4}$ & Small-city region & 1545 \\
\hline$x_{5}$ & Rural region & 589 \\
\hline \multicolumn{3}{|c|}{ Sector (classification of industry) } \\
\hline$x_{6}$ & Primary industry & 107 \\
\hline$x_{7}$ & $\begin{array}{l}\text { Low-tech manufacturing industry and } \\
\text { mining }\end{array}$ & 6045 \\
\hline$x_{8}$ & High-tech manufacturing industry & 752 \\
\hline$x_{9}$ & Trade and transport & 3566 \\
\hline$x_{10}$ & Knowledge intensive services & 1822 \\
\hline \multicolumn{3}{|c|}{ Size of the firm } \\
\hline$x_{11}$ & Employees between 5-9 & 1722 \\
\hline$x_{12}$ & Employees between 10-19 & 2080 \\
\hline$x_{13}$ & Employees between 20-49 & 2499 \\
\hline$x_{14}$ & Employees between 50-99 & 1243 \\
\hline$x_{15}$ & Employees 100+ & 980 \\
\hline
\end{tabular}

\begin{tabular}{lcc}
\hline \multicolumn{3}{c}{ Regional collaboration with other firms in the innovation process } \\
\hline$x_{16}$ & Regional collaboration \\
\hline \multicolumn{3}{c}{ Capital } \\
\hline$x_{17}$ & Own-financed R\&D \\
\hline$x_{18}$ R\&D personnel \\
\hline \multicolumn{2}{c}{ Cirms with R\&D employees } \\
\hline$\alpha$ & Constant \\
\hline
\end{tabular}

Note that we have included a constant term $\alpha$ which measures the effects from the "benchmark" category, and the estimated logit coefficient 
has the following interpretation: $\alpha$ is the predicted logit or log odds ratio of innovation by a firm which has the following properties: (a) the firm is located in a rural region, (b) it belongs to the low-tech manufacturing industry, (c) the firm does not own-finance the R\&D activity and (d) the firm employs between 5 and 9 persons. Note that the estimated slope coefficient $\beta_{\mathrm{j}}$ measures the difference in the log odds ratio of innovation for a firm with the corresponding attribute $x_{j}$ relative to the base or reference category which is measured by the constant term $\alpha$. The coefficients in the model are estimated with a maximum likelihood routine. The log odds ratio and likelihood are used interchangeable in the text because likelihood

of innovation can be expressed as $\operatorname{Pr}(y=1)=\left[1+e^{-\left(\alpha+\sum_{j=1}^{k} \beta_{j} x_{j}\right)}\right]^{-1}$ and increasing (decreasing) value on the estimated coefficients $\alpha$ and $\beta_{j}$, increases (decreases) the log odds ratio and equivalently the likelihood or probability of a defined event $y=1$.

\section{RESULTS}

\section{Attributes' influence on innovation}

In this section, we present the results of our statistical analysis which is based on 8524 observations. We will discuss how these various attributes are an influence on firms' propensity to innovate. Table 2 shows the estimated coefficients and statistical properties (asymptotic standard errors and $t$-values).

In this section, we discuss the results of the unweighted estimated relationship between the likelihood of innovation and the explanatory variables.

Overall evaluation of the model: The likelihood ratio test of the following null hypothesis $\mathrm{H}_{0}$ : the variables included in the model do not have any influence on the likelihood of innovation, i.e. we test the following nullhypothesis; $\mathrm{H}_{0}: \beta_{1}=\beta_{2}=\ldots . .=\beta_{15}=0$, and the result of the log-likelihood chi-square test is: $\lambda=2395$ with 15 degrees of freedom and $p$-value $=0.00$. The null hypothesis is rejected and we conclude that the model has explanatory power. The model predicts correctly $56.1 \%$ of the cases where firms actually report one or more innovation, and the model predicts correctly $91.3 \%$ where firms actually did not register any innovation. 
Table 2. Estimated coefficients

\begin{tabular}{|c|c|c|c|}
\hline Variable name & $\begin{array}{l}\text { Estimated } \\
\text { coefficient }\end{array}$ & $\begin{array}{l}\text { Asymptotic } \\
\text { standard error }\end{array}$ & $\begin{array}{l}\text { Asymptotic } \\
t \text {-value ( } p \text {-value) }\end{array}$ \\
\hline$x_{4}:$ Small region & $\beta_{4}=0.199 *$ & 0.116 & $1.715(0.086)$ \\
\hline$x_{3}:$ Medium region & $\beta_{3}=0.186^{*}$ & 0.110 & $1.685(0.091)$ \\
\hline$x_{2}:$ Metropolitan region & $\beta_{2}=0.281^{* *}$ & 0.114 & $2.461(0.013)$ \\
\hline$x_{1}:$ Capital region & $\beta_{1}=0.357 * * *$ & 0.115 & $3.111(0.002)$ \\
\hline$x_{6}:$ Primary industry & $\beta_{6}=-0.049$ & 0.025 & $-0.195(0.845)$ \\
\hline$x_{8}:$ High-tech manufacturing & $\beta_{8}=0.003$ & 0.104 & $0.259(0.979)$ \\
\hline$x_{9}:$ Trade and transport & $\beta_{9}=-0.181 * * *$ & 0.063 & $-2.874(0.004)$ \\
\hline$x_{10}:$ Knowledge-intensive services & $\beta_{10}=0.019$ & 0.077 & $0.254(0.799)$ \\
\hline$x_{12}:$ Employees 10-19 & $\beta_{12}=0.144^{*}$ & 0.075 & $1.915(0.055)$ \\
\hline$x_{13}:$ Employees 20-49 & $\beta_{13}=0.234^{* * *}$ & 0.073 & $3.214(0.001)$ \\
\hline$x_{14}:$ Employees 50-99 & $\beta_{14}=0.317^{* * *}$ & 0.088 & $3.610(0.000)$ \\
\hline$x_{15}:$ Employees $100+$ & $\beta_{15}=0.431 * * *$ & 0.098 & $4.419(0.000)$ \\
\hline $\begin{array}{c}x_{18}: \text { R\&D Employees with "high" } \\
\text { (academic) education }\end{array}$ & & 0.142 & $1.488(0.136)$ \\
\hline $\begin{array}{l}x_{16}: \text { Regional collaboration of } \\
\text { innovation }\end{array}$ & $\beta_{16}=1.023 * * *$ & 0.100 & $10.228(0.000)$ \\
\hline$x_{17}:$ Own-financed innovation & $\beta_{17}=2.053^{* * *}$ & 0.131 & $15.668(0.000)$ \\
\hline CONSTANT & $\alpha=-1.141^{* * *}$ & 0.116 & $-9.814(0.000)$ \\
\hline
\end{tabular}

Note: $* * *, * * *$ Indicate significance coefficients at the 1,5 and $10 \%$ level in a two-sided t-test, respectively. Critical values for one-sided tests given 10 and 5\% significance levels are 1.28 and 1.65, respectively. Software package Shazam is applied in the estimation of the model.

The overall percentage correct prediction $\left(\right.$ Count $\left.-R^{2}\right)$ is $74.6 \%$. The cut value is 0.5 . The model has clearly explanatory power and the conclusion is as well supported by McFadden's ratio $R^{2}=1-\frac{L(\boldsymbol{\beta})}{L(0)}=0.20$, which is relatively high (Allison, 2012).

$L(\boldsymbol{\beta})$ is the maximum likelihood of the unrestricted model while $L(0)$ is the maximum likelihood of the restricted model when the coefficients are all zero except the constant term.

Firm size: The size of a firm can play a role in the innovation process and the variable represents a firm-specific attribute. According to the firmoriented theories, large firms have more differentiated and specialized teams of employees than smaller firms with fewer resources and a more differentiated human capital base which is advantageous for innovation. In addition, we expect that large firms have a greater opportunity to utilize economies of scale and scope. We tested statistically the null-hypothesis $\mathrm{H}_{0}$ : that the likelihood of innovation does not increase with the size of the 
firm. The estimation shows that we can reject the null-hypothesis because the estimated logit coefficients for the size variables $\left(\beta_{12^{\prime}}, \beta_{13^{\prime}} \beta_{14^{\prime}} \beta_{15}\right)$ are all significantly different from zero. According to the values of the coefficients the likelihood of innovation increases with the size of the firm. The estimation and associated tests show that the size of a firm plays an important role in the likelihood of innovation. The general conclusion is that the larger a firm is, the more likely it is to innovate.

Sector: Our classification of industry branches is broad, but not so rough that we cannot say something meaningful about the relative rates of innovation. In general, we expect innovation in all groups, but according to theory we expect the "high-tech" manufacturing industry and the knowledgeintensive service sector to generate more innovation than the other groups, especially compared to the reference group which is the low-tech manufacturing industry and mining industry located in rural areas. According to the model the estimated likelihood of innovation in the reference group is (Formula 2):

$$
\operatorname{Pr}(y=1)=\frac{1}{1+e^{-\alpha}}=\frac{1}{1+e^{-(-1.1409)}} \approx 0.24
$$

The estimated likelihood of innovation in these sectors is 0.24 which implies that about one out of four firms in this category has innovated.

The estimation shows that the logit coefficients for the high-tech manufacturing industry $\left(\beta_{8}\right)$ and firms in the knowledge intensive sector $\left(\beta_{10}\right)$ are not significantly different from zero even though the value of the estimated logit coefficients are higher. The result implies that the likelihood of innovation in these sectors does not differ significantly compared to the likelihood of innovation in the reference group which is about 0.24 . On the other hand, the estimated model shows that the likelihood of innovation in the trade and transport sector is lower compared to firms in other groups because the logit coefficient $\left(\beta_{9}\right)$ is significantly lower than zero. The likelihood of innovation in the trade and transport group $\left(x_{9}\right)$ is as follows (Formula 3 ):

$$
\operatorname{Pr}(y=1)=\frac{1}{1+e^{-\left(\alpha+\beta_{9}\right)}}=\frac{1}{1+e^{-(-1.1409-0.18055)}} \approx 0.21
$$

According to both the resource based and the evolution theory of firms, we expect that "high-tech" and "knowledge-intensive" services have a higher likelihood of innovation than the reference category. A closer look at the estimated coefficients shows that the ranking of the industry groups is consistent with theory, but the logit coefficients are not significant. 
R\&D personnel: R\&D personnel are dedicated to research and innovation within the firm, and thus they contribute to innovation. According to the definition applied in the survey, R\&D personnel have at least five years of higher education (master's degree or similar). We expect, according to the firm-oriented theories and especially the resource-based view, that firms with dedicated R\&D personnel are more innovative than other firms. We tested the hypothesis $\mathrm{H}_{0}$ : The likelihood of innovation within firms with R\&D personnel is not different from the reference group. The null hypothesis implies a test whether the estimated logit coefficient $\beta_{18}=0$. The statistical test shows that the null-hypothesis is not rejected because the $t$-value ( $t=1.49$ and $p$-value $=0.14$ ) is lower than the critical value $t^{c}=1.96$.

Own-financed R\&D: According to the firm-oriented theories we expect that firms that are in the position of financing R\&D have a higher likelihood of innovation compared to firms which are not in that position. The expectation is evaluated by testing the following null-hypothesis $\mathrm{H}_{0}: \beta_{17}=0$. The nullhypothesis is clearly rejected ( $p$-value $=0.00$ ). The estimation shows that internal funding of R\&D has a strong positive and statistically significant effect on the likelihood of innovation. The size of the estimated coefficients and associated asymptotic $t$-values show that the willingness to use their own capital resources has the largest effect on the likelihood of innovation. According to the firm-oriented perspective on innovation, companies that are willing to spend their own capital resources on R\&D also reveal the preference that the expected rate of return on the investment in R\&D and innovation is equal or larger compared to the risk-adjusted return on the best alternative allocation of the capital. Further, firms that own-finance the $R \& D$ are also in the position of controlling the project and expropriating the economic rent or excess profit generated from innovations. We therefore suspect that the variable "own-financed R\&D" is to some extent biased towards high probability of innovation.

The size of the region: According to the regional system-oriented approach to innovation, regions with a high number of people have more human resources, more accumulated knowledge and a "thicker" institutional infrastructure compared to regions with a smaller number of people. We evaluated this assumption by testing the following null hypothesis $\mathrm{H}_{0}$ : The likelihood of innovation is not increasing with the number of people in the region where the firms are located. The null hypothesis implies that we test whether the following logit coefficients in the model are zero, i.e. $\mathrm{H}_{0}: \beta_{4}=\beta_{3}=\beta_{2}=\beta_{1}=0$. According to the null-hypothesis we should not expect the alternative hypothesis which states that $\beta_{4}<\beta_{3}<\beta_{2}<\beta_{1}$. The estimation shows not only that the $\beta$ s actually are significantly different from zero, but the value of the coefficients are increasing in the following way $\beta_{4}=\beta_{3}<\beta_{2}<\beta_{1}$. Note that 
the values of the coefficients $\beta_{4}$ and $\beta_{3}$ are not significantly different from each other. The estimation shows that there is a positive relationship between the size of the region where the firms are located and the firms' probability of innovation. The likelihood of innovation for firms in rural areas (regions with fewer than 10,000 inhabitants) is significantly lower relative to the other four types of regions. The largest likelihood of innovation is estimated for firms in the capital region (i.e. the region with the highest number of inhabitants). In summary the estimation and tests indicate that the likelihood of innovation is significantly greater in the capital region relative to the other regions except for the medium-city area, and that there is a tendency that the likelihood of innovation increases with the size and the endowment of resources in the region.

The quality of the region: Within the system perspective it is argued that networking is important for innovation. Somewhat simplified, it is anticipated that firms can either be located in regions with a high degree of regional collaboration and networking (so-called high quality regions) or be located in regions which lack co-operating partners and network arrangements (socalled low quality regions). We believe that observed regional networking of firms indirectly reflects such qualities of the region. Variable $x_{16}$ in the model measures whether firms cooperate and are an integrated part of a network of firms. We evaluate whether cooperation has any influence on innovation by testing the null-hypothesis $\mathrm{H}_{0}: \beta_{16}=0$. The result of the test rejects the null-hypothesis ( $p$-value $=0.00$ ). The analysis clearly indicates that regional collaboration has a significant positive effect on the likelihood of innovation. Thus, the likelihood of innovation is larger for firms that collaborate with regional actors than for firms that are not involved in such collaboration. The reason that the latter are not involved in regional collaboration can either be a lack of potential partners in the region or that the single firm does, for different reasons, not embrace the possibility of such regional collaboration.

\section{DISCUSSION AND CONCLUSIONS}

The objective of the paper was to combine different perspectives on innovation and analyse why some firms innovate while others do not, i.e., to find out why some firms, but not all, are in the position of generating new products, new methods of production, or developing new ways of organizing the business or exploiting new markets. The review of the theories shows that innovation in firms is critically conditioned on whether firms are endowed with a set of unique resources or assets and are operating in a socio-economic environment which stimulates innovation. In the empirical part of the paper we have integrated different theories of innovation in a 
single regression model and tested simultaneously properties based on both theories, rather than applying the theories separately, side-by-side.

From regional system and firm-oriented theories we derived attributes which measure properties and characteristics which influence the likelihood of innovation. Four of these explanatory attributes are firm-related (size, sector, R\&D personnel and own-financed R\&D) and two are regional characteristics (size and quality of the region which are proxy variables for the endowment of resources in the region). The empirical part of the paper applied data provided by the Community Innovation Survey of innovation among firms in Norway. We applied logistic regression methodology in analysing whether the derived attributes have any influence on the firms' propensity to innovate. The main conclusions from the empirical analysis are as follows:

Size of the firm: The estimation and tests showed that the size of the firm plays an important role and affects the likelihood of innovation. The larger the firm is, the more likely it is to innovate. The finding confirms the firmoriented theories which emphasize that larger firms have more resources and assets to generate innovation compared to smaller firms.

Sector: The estimated model showed that the likelihood of innovation was similar across categories of industry sectors, except that the likelihood of innovation was significant lower in the trade and transport sector. The estimation shows that innovation rates across industries are almost identical. The finding could in the first place be perceived as a contradiction of the firmoriented theory of innovation because theory predicts that knowledge and capital-intensive industries have a higher propensity to innovate compared to low-tech, traditional industries. The findings do not support the theory. However, we argue that relatively similar innovation rates are not necessarily a falsification of the theory because the type of innovation and effort behind it could differ substantially between industries, and we should be open to the argument that comparing innovation across industries could be inconsistent, in the sense that sophisticated, time and capital intensive product innovations are not equal to marginal and low cost incremental innovations. Both are registered as an innovation and treated equally in the survey, even though they could be completely different with respect to effort, spent resources and innovation novelty. These remarks are topics for further research.

$R \& D$ personnel: We tested the hypothesis whether firms with $R \& D$ personnel are more innovative than other firms. The statistical model showed that firms with R\&D personnel have a positive effect on the likelihood of innovation, but the effect is not significantly higher compared to other firms. We presented the following remark which could explain the empirical result: The Norwegian Community Innovation Survey does not take into account 
that "innovation" is a heterogeneous product or process across industry sectors and the firms' characteristics, and we argued that firms with R\&D personnel work in a field of innovation that is intellectually complicated and capital intensive.

Own-financed R\&D: The size of the estimated logit coefficients and associated $t$-values indicate that internal funding of R\&D has a large positive effect on the firms' likelihood of introducing an innovation. The result supports the firm-oriented theory of innovation. We argue, without any empirical verification, that the strong effect could partly be explained that firms are anticipating that investments in these types of innovation projects are exposed to a relatively low economic risk, and partly that firms expect to expropriate a large part of the economic rent or profit generated by the innovation. These explanations could therefore produce biasness toward successful innovation, and statistically a strong result. We could add to this point that firms that are able to fund the R\&D are already well run, successful firms. Successful innovation makes them even more competitive and profitable which in the next round have a positive effect on the firms' ability to fund R\&D. We can therefore not exclude that there is a positive feedback effect between profitability, ability to fund R\&D, and successful innovation. This is a topic for further research and whether these arguments are supported empirically.

The size of the region: The size of the region is a proxy variable for endowment of resources and competence in the region. The estimation showed a significant positive relation between the size of the region where the firms are located and the probability of innovation. The largest likelihood of innovation was estimated for firms in the capital region (i.e. the region with the highest number of inhabitants and variety of institutions), and the lowest for firms located in rural areas (regions with fewer than 10000 inhabitants). The findings support the regional system-oriented theory of innovation.

The quality of the region: We believe that observed regional networking of firms indirectly reflects the qualities of the region, i.e. whether the milieu is stimulating regional collaboration or not. We found that regional collaboration has a significant and positive effect on the likelihood of innovation. Thus, the likelihood of innovation is larger for firms that collaborate with regional actors compared to firms that are not involved in such collaboration. The result supports the regional system-oriented theory of innovation.

The main objective of the analysis was to combine theories which could provide us with a broader understanding of why some firms innovate and others not. The explanation behind "why" is based on theoretical and empirical analyses of how firm-specific and regional characteristics are an influencing on a firm's propensity to innovate. According to the estimated 
logit coefficients, a firm's ability to fund R\&D is the most important firm characteristic for innovation. Companies that are in a position to use internal resources to fund R\&D are much more likely to develop innovations. When a firm is able to fund its own research, it increases the probability of innovation significantly. The sample data also show that there is a positive correlation between the size of the firm and whether a firm has R\&D personnel and/ or are able to own-finance R\&D-activity. Firms with these characteristics are first of all involved in product-innovation. The size of the firm is the second most important firm characteristic linked to a high rate of innovation. The larger a firm is, the more likely it is to innovate. The most important regional characteristic is geographical proximity to innovation partners, i.e. the quality of the regional system with respect to interaction between firms and institutions. Firms that utilize this resource and set up partnerships with other actors in their region are significantly more innovative than firms that lack such regional partnerships. We also found that firms in larger urban regions were more likely to innovate than firms in rural areas.

The analysis has several implications for industrial innovation policies and we will sketch some of these as follows: First, successful innovation is related to internal funding. It implies that the business tax system can be adjusted to give firms stronger incentives to spend its own resources on $R \& D$, for example by using instruments that reduce the exposition of risk associated to a project. Second, there is a significant positive correlation between the size of the firm and financing its own R\&D. Since own financing R\&D has a positive influence on the likelihood of innovation, it will have implication for the industry policy which aims to stimulate innovation in small firms. Third, public innovation policies should invest in infrastructure and stimulate networking among firms because it increases interaction and contributes to positive economies. The policy should provide small firms with incentives to co-operate with and learn from larger firms located in the same region. In order to increase the expected effect from industrial innovation policies, innovation instruments should be conditional on firms taking part in networking and innovation collaboration with other firms. Fourth, innovation policies should consider allocating relatively more economic resources, human capital and competence to rural areas in order to compensate for asymmetric distribution of resources between the centre and periphery.

\section{References}

Allison, P. (2012). Logistic Regression Using SAS: Theory and Application. Carry, NC: SAS Institute 2012.

Audretsch, D. B., \& Feldman, M. P. (1996). R\&D spillovers and the geography of innovation and production. American Economic Review, 86, 630-640. 
Audretsch, D. B., \& Feldman, M. P. (2004). Knowledge spillovers and the geography of innovation. In J. V. Henderson, \& J.-F. Thisse (Eds.), Handbook of Urban and Regional Economics: Cities and Geography (pp. 2713-2739). Amsterdam: Elsevier.

Autio, E. (1998). Evaluation of RTD in regional systems of innovation. European Planning Studies, 6, 131-140.

Chandler, A. D., Jr. (1966). Strategy and Structure. New York (US): Anchor Books.

Christensen, C. M., \& Raynor, M. E. (2003). Six Keys to Creating New-Growth Businesses. Boston: Harvard Business School Press.

Clausen, T. H. (2013). External knowledge sourcing from innovation cooperation and the role of absorptive capacity: empirical evidence from Norway and Sweden. Technology Analysis \& Strategic Management, 25, 57-70.

Cooke, P. (1992). Regional innovation systems: Competitive regulation in the new Europe. Geoforum, 23, 365-382.

Cooke, P. (2001). Regional innovation systems, clusters and the knowledge economy. Industrial and Corporate Change, 10, 945-974.

Cooke, P. (2012). Knowledge economy spillovers, proximity and specialization. In B. T. Asheim, \& M.D. Parrilli (Eds.), Interactive Learning for Innovation. A Key Driver Within Cluster and Innovation System (pp. 100-114). Basingstoke (UK): Palgrave Macmillan.

Enkel, E., Gassmann, O., \& Chesbrough, H. (2009). Open R\&D and open innovation: Exploring the phenomenon. R\&D Management, 39, 311-16.

Fabrizio, K. R., \& Thomas, L.G. (2011). The impact of local demand on innovation in a global industry. Strategic Management Journal, 33, 4264.

Fagerberg, J. (2005). Innovation: A guide to the literature. In J. Fagerberg, D. Mowery, \& T. R. Nelson (Eds.), The Oxford Handbook of Innovation (pp. 1-27). Oxford (UK): Oxford University Press.

Fagerberg, J. (2009). Introduction: Innovation in Norway. In J. Fagerberg, D. C. Mowery, \& B. Verspagen (Eds.), Innovation. Path Dependency and Policy (pp. 1-32). Oxford (UK): Oxford University Press.

Fløysand, A., \& Jakobsen, S.-E. (2011). The complexity of innovation. A relational turn. Progress in Human Geography, 35, 328-344.

Fløysand, A., \& Jakobsen, S-E. (2016). In the footprints of evolutionary economic geography. Norwegian Journal of Geography, 70, 137-139.

Fløysand, A., Jakobsen, S-E., \& Bjarnar, O. (2012). The dynamism of clustering: Interweaving material and discursive processes. Geoforum, 43, 948-958.

Fløysand, A., Jakobsen, S-E., \& Sánchez-Hernández, J. L. (2014). Regional industrial policy in Norway and Spain. In R. Baptista, \& J. Leitao (Eds.), Entreprenurship, Human Capital and Regional Development - Labour Networks, Knowledge Flows and Industry Growth (pp. 309-331). New York (US): Springer. 
Foss, N. J., Knudsen, C., \& Montgomery, C. A. (1995). An exploration of common ground: Integrating evolutionary and strategic theories of the firm. In C. A. Montgomery (Ed.), Resource-Based and Evolutionary Theories of the Firm: Toward a Synthesis (pp. 1-17). Boston (US): Kluwer Academic Publishers.

Freeman, C. (1987). Technology Policy and Economic Performance: Lessons from Japan. London (UK): Pinter.

Fritsch, M. (2003). Does R\&D-cooperation behavior differ between regions?. Industry and Innovation, 10, 25-39.

Hoover, E. M. (1954). Location Theory and the Shoe and Leather Industries. Cambridge (US): Harvard University Press.

Isaksen, A., \& Onsager, K. (2010). Regions, networks and innovative performance. The case of knowledge-intensive industries in Norway. European Urban and Regional Studies, 17, 227-243.

Isaksen, A., \& Trippl, M. (2014). Regional industrial path development in different regional innovation systems: A conceptual analysis. Papers in innovation studies, paper no. 2014/17, CIRCLE, Lund University.

Jakobsen, S-E., \& Lorentzen, T. (2015). Between bonding and bridging: Regional differences in innovative collaboration in Norway. Norwegian Journal of Geography, 69(2), 80-89.

Jakobsen, S-E., Byrkjeland, M., Båtevik, F. O., Pettersen, I. B., Skogseid, I., \& Yttredal E. R. (2012). Continuity and change in path dependent regional policy development: The regional implementation of the Norwegian VRI programme. Norwegian Journal of Geography, 66, 133-143.

Jukvam, D. (2002). Inndeling i bo-og arbeidsmarkedsregioner. NIBR-Rapport 2002:20. Norsk Institutt for by-og Regionsforsking (In Norwegian). Oslo.

Laursen, K. Masciarelli, F., \& Prencipe, A. (2012). Regions matter: how localized social capital affects innovation and external knowledge acquisition. Organization Science, 23, 177-193.

Lawson, B., \& Samson, D. (2001). Developing innovation capability in organisation: A dynamic capability approach. International Journal of Innovation Management, 5, 377-400.

Lazonick, W. (2005). The innovative firm. In J. Fagerberg, D. Mowery, \& T. R. Nelson (Eds.), The Oxford Handbook of Innovation (pp. 29-55). Oxford (UK): Oxford University Press.

Lundvall, B. Å. (1992). Introduction. In B. Å. Lundvall (Ed.), Systems of Innovations (pp. 1-19). London (UK): Pinter Publishers.

Malecki, E. J. (2012). Regional Social Capital: Why it Matters. Regional Studies, 46(8), 1023-1039.

Marshall, A. (1920). Principles of Economics: An Introductory Volume, 8th edition. London (UK): Macmillan.

Martin, R. (2010). Roepke lecture in economic geography - rethinking regional path dependence: Beyond lock-in to evolution. Economic Geography, 86, $1-27$. 
Martin, R., \& Sunley, P. (2006). Path dependence and regional economic evolution. Journal of Economic Geography, 6, 395-437.

Nelson, R. R. (1991). Why do firms differ, and how does it matter?. Strategic Management Journal, 12, 61-74.

Nelson, R. R., \& Winter, S. G. (1982). An Evolutionary Theory of Economic Change. Cambridge (US): The Belknap Press.

Newell, R. G., Jaffe A. B., \& Stavins, R. N. (1999). The induced innovation hypothesis and energy-saving technological change. Quarterly Journal of Economics, 114, 941-975.

Njøs, R., Jakobsen, S-E., \& Rosnes, V. (2016). Market-driven organizational lock-in. A case study of a former first mover. Norwegian Journal of Geography, 70, 140-151.

Njøs, R., Jakobsen, S-E., Fosse J. K., \& Engelsen, C. (2013). Challenges to Bridging Discrepant Knowledge Bases: A Case Study of the Norwegian Centre for Offshore Wind Energy. European Planning Studies, 22 (11), 2389-2410.

Penrose, E. T. (1959). The Theory of the Growth of the Firm. Oxford (UK): Basil Blackwell.

Porter, M. (2000). Location, competition and economic development: local clusters in a global economy. Economic Development Quarterly, 14, 1534.

Rangone, A. (1999). A resource-based approach to strategy analysis in smallmedium sized enterprises. Small Business Economics, 12, 233-248.

Schumpeter, J. (1934). The Theory of Economic Development. Cambridge (US): Harvard University Press.

Schumpeter, J. (1943). Capitalism, Socialism and Democracy. New York (US): Harper.

Simmie, J. (2003). Innovation and urban regions and national and international nodes for the transfer and sharing of knowledge. Regional Studies, 37, 607-620.

Teece, D. J., \& Pisano, G. (1994). The dynamic capabilities of firms: An introduction. Industrial and Corporate Change, 3, 537-556.

Teece, D. J., Pisano, G., \& Shuen, A. (1997). Dynamic capabilities and strategic management. Strategic Management Journal, 18, 509-533.

Tödtling, F., \& Trippl, M. (2005). One size fits all? Towards a differentiated regional innovation policy approach. Research Policy, 34, 1203-1219.

Tödtling, F., \& Trippl, M. (2007). Knowledge links in high-technology industries. Markets, networks or milieu? The case of the Vienna biotechnology cluster. International Journal of Entrepreneurship and Innovation Management, 7, 345-365.

Trott, P. (2012). Innovation Management and New Product Development. 5th Edition. London (UK): Prentice Hall.

Tushman, M. L., \& O’Reilly III, C.A. (2002). Winning through innovation. A practical guide to leading organizational change and renewal. Boston (US): Harvard Business School Press. 
Vatne, E. (2011). Regional agglomeration and growth: the classical approach. In P. Cooke, B. T. Asheim, R. Boschma, R. Martin, D. Schwartz, \& F. Tödtling (Eds.), Handbook of Regional Innovation and Growth (pp. 5466). Cheltenham (UK): Edward Elgar.

Wernerfelt, B. (1984). A resource-based view of the firm. Strategic Management Journal, 5, 171-180.

Whistler, D., White, K., Bates, D., \& Golding M. (2011). Shazam: We have applied SHAZAM software package, Version 11, for statisticians to estimate the model. SHAZAM Analytics, Ltd. Retrieved from www. shazamanalytics.com/

\begin{abstract}
Polish)
Celem artykułu jest analiza, dlaczego niektóre firmy sq innowacyjne, a inne nie. Artykuł łq̨czy różne teorie innowacji poprzez odniesienie do innowacji wewnętrznych, aktywów i zewnętrznych czynników regionalnych. Hipotezy sq uzyskiwane z teorii i testowane empirycznie za pomoca regresji logistycznej. Analiza empiryczna wskazuje, że wewnętrzne finansowanie $B+R$ i wielkość firmy sq najważniejszymi firmowymi i specyficznymi atrybutami udanej innowacji. Zewnętrzne, regionalne czynniki sq również ważne. Z analizy wynika, że firmy zlokalizowane w dużych obszarach miejskich maja znacznie wyższe wskaźniki niż innowacyjne firmy zlokalizowane na peryferiach, a firmy zaangażowane w sieci regionalnej sq bardziej skłonne do innowacji w stosunku do firm nie uczestniczqcych w sieci. Analiza przyczynia się do teoretycznego i empirycznego zrozumienia czynników, które majq wpływ na innowacyjność i rolę, jakq odgrywa innowacja w gospodarce rynkowej. Polityka innowacji powinna być ukierunkowana na rozwój infrastruktury systemu podatkowego i budowlanego, które daja firmom zachęty do inwestowania i alokacji zasobów wewnętrznych $w$ działalność $R \& D$ oraz współpracy z innymi w zakresie innowacji. Z punktu widzenia polityki gospodarczej, należy zwrócić uwagę na przeznaczenie większych środków publicznych na obszarach wiejskich, w celu zrekompensowania asymetrycznego podziału środków między centrum a peryferiami. Artykut przyczynia się do rozwoju literatury naukowej z zakresu innowacyjności, łączq̨c specyficznq, firmowa perspektywę z zasobami wewnętrznymi i perspektywq systemowq, która koncentruje się na zasobach zewnętrznych i sieci jako najważniejszej determinanty innowacyjności w firmach.
\end{abstract}

Słowa kluczowe: innowacje, region, lokalizacja, centrum i peryferia, firmowe $i$ zewnętrzne zasoby, networking, przemysł norweski, regresja logistyczna.

\title{
Biographical notes
}

Torbjørn Lorentzen has a Master's degree in economics from the University of Bergen, Norway and he is a senior scientist at Uni Research A/S, Bergen, Norway. His main research subjects include econometrics, market and structural analysis and the socio-economic impacts of climate change. 
Stig-Erik Jakobsen is Professor in economic geography and runs the Centre for Innovation at the Bergen University College. He holds a Ph.D. from the University of Bergen, and is experienced in studies of industrial development and processes of learning, networking and innovation within various milieus and sectors. His core expertise lies within analyses of the systemic nature of innovation, the evolution of clusters and innovation policy design, and he has an extensive publication record in international journals. 
